\title{
Seroepidemiology of Neospora Caninum in Dairy Cattle Farms with a History of Abortion in Isfahan Province, Iran
}

\author{
Morovati $\mathrm{H}^{1}$ and Noaman $\mathrm{V}^{* 2}$ \\ ${ }^{1}$ Quality Control Management, Razi Vaccine and Serum Research Institute, AREEO, Karaj, Iran \\ ${ }^{2}$ Veterinary Research Department, Isfahan Agriculture and Natural resources Research and Education Center, \\ AREEO, Isfahan, Iran
}

${ }^{*}$ Corresponding author: Noaman V, Veterinary Research Department, Isfahan Agriculture and Natural resources Research and Education Center, AREEO, Isfahan, Iran, E-mail: vnoaman@gmail.com

Citation: Morovati H, Noaman V (2016) Seroepidemiology of Neospora Caninum in Dairy Cattle Farms with a History of Abortion in Isfahan Province, Iran. J Vet Sci Anim Husb 4(3): 304

Received Date: October 05, 2016 Accepted Date: November 21, 2016 Published Date: November 23, 2016

\begin{abstract}
Background: Neospora caninum is a worldwide-distributed pathogen which causes abortions in dairy cattle, leading to economic losses in the cattle industry. The main objectives of the present work was to determine the seroprevalence of $N$. caninum antibodies in dairy cattle farms in Isfahan province, central Iran and to investigate the factors associated with the infection.

Methods: 611 sera from Holstein dairy cattle were collected from 25 farms with an abortion history. The sera were divided according to age, pregnancy, lactation state, farm type, feed and contact with caniide. The antibodies to $N$. caninum were detected using a commercially available ELISA kit.

Results: N. caninum antibodies were detected in $32.1 \%$ of the sera and $96 \%$ of the farms. The percentage of infection of animals in different farms ranged from $0.0 \%$ to $60 \%$ which is statistically significant difference $(p<0.05)$. N. caninum seroprevalence was significantly higher in pregnant cattle as compared to that in non-pregnant cattle $(p<0.05)$. Also cattle contact to watch- dog and wildcaniide showed a higher seroprevalence than cattle contact alone to watch-dog $(p<0.05)$. No statistically significant difference in $N$. caninum seroprevalence was noted between age groups, lactation states, farm types, and cattle feed groups $(p>0.05)$.
\end{abstract}

Conclusion: The results demonstrate that the seroprevalence of N. caninum is relatively high in cattle from the Isfahan province, central Iran. Further investigation is needed for the confirmation of infection and to confirm the effects of co-infection on N. caninum infection in cattle.

Keywords: Neospora caninum; Sero-epidemiology; Dairy cattle; Isfahan; Iran

\section{Introduction}

Neospora caninum (Apicomplexa: Toxoplasmatinae) is a worldwide-distributed pathogen which causes abortions in beef and dairy cattle in many countries around the world, leading to economic losses in the cattle industry [1,2]. N. caninum has a two-host life cycle, including intermediate hosts (mainly cattle and other warm-blooded animals) and definitive hosts (dogs and coyotes) $[3,4]$. In cattle, transplacental transmission from infected cows to their offspring appears to be the major natural route of infection, and congenitally infected calves remain persistently infected and can pass the infection to their offspring [5]. Dogs and coyotes are the only species recognized as acting as the definitive hosts, in which the sexual phase of development of N. caninum occurs, resulting from the shedding of oocysts in the feces $[4,6,7]$. However, the exposure to N. caninum, through oocyst-contaminated food or drinking water, is regarded as the most probable cause of infection in some herds $[8,9]$. Cows infected with $N$. caninum, both acutely and chronically, have up to $5.7-18.9 \%$ higher risk of abortion than non-infected cows [10,11]. Diagnosis of N. caninum infection in these cases has been based largely on the serological testing by immunofluorescence assay (IFA) or enzyme-linked immunosorbent assay (ELISA) of serum from all or parts of the affected dairy herds.

In Iran, the presence of N. caninum antibodies has been described in cattle but a few serological surveys carried out for the detection of N. caninum infection in different parts of our country [12]. The main objectives of the present work was to determine the seroprevalence of N. caninum antibodies in dairy cattle farms in Isfahan province (in center of Iran), and to investigate the factors associated with the infection. 


\section{Materials and Methods}

\section{Study area}

The study was carried out on Holstein dairy cattle farms around Isfahan (latitude $30^{\circ} 43^{\prime}-34^{\circ} 27^{\prime} \mathrm{N}$, longitude $49^{\circ} 36^{\prime}-55^{\circ} 31^{\prime} \mathrm{E}$ ). Isfahan is located in center of Iran, in the lush plain of the Zayandeh River, at the foothills of the Zagros mountain range. The city situated at 1590 meters above sea level, enjoys a temperate climate and regular seasons and is very hot during the summer with maxima typically around $36^{\circ} \mathrm{C}\left(97^{\circ} \mathrm{F}\right)$. However, it has low humidity and moderate temperatures at night. During the winter, days are mild but nights can be very cold. Its annual precipitation is 113 millimetres.

\section{Animals}

The population targeted was 611 dairy cows (Holstein-Friesian) from 25 industrial and non-industrial farms randomly selected in the North, South, East and West of Isfahan. Farms were selected by stratified random sampling method. Based on the previous studies the prevalence of Neospora antibody was 30\% and a 5\% tolerable error was assumed when determining the desired sample size of cattle to be sampled. The cattle sample size (322) was determined according to the random sample size formula where 1.96 was the $\mathrm{z}$ value for the desired confidence level (95\%). By sampling animals dependent on farm herd size, and reducing the clustering effect a final sample size of 611 animals were sampled and examined in this study.

Range of sampled cows on the farms was from 5 to 56 animals. According to the farm records, abortion had been observed on the all farms. Cattle were grouped according to age (under 12 months: 109; 12-24 months: 105; and over 24 months: 397), Pregnancy (Pregnant: 355; and Non-pregnant:256), Lactation state (Lactated cows: 460; and Non-lactate cows: 151), Farm type (industrial: 489 and non-industrial: 122), Feed (Dried alfalfa+ silage +concentrate: 489; and Fresh alfalfa+ dried alfalfa+ silage +concentrate: 122) and the Contact with caniide (Watchdog: 493; and Watchdog and wild caniide:118).

\section{Sampling}

Samples of blood serum from female cattle were examined. Blood samples were taken using disposable needles (venoject) (Ava Co., Tehran, Iran). All samples were immediately transported to the diagnostic laboratory. Serum was removed after centrifugation at $1000 \mathrm{x} g$ for $10 \mathrm{~min}$. All sera were divided equally into two micro tubes and stored at $-20^{\circ} \mathrm{C}$ until tested.

\section{ELISA test}

The antibodies to N. caninum were detected using a commercially available ELISA kit (enzyme-linked immunosorbent assay; IDEXX Laboratories Inc., Westbrook, Maine, USA), following the manufacturer's instruction. Briefly each serum sample (diluted 1:100) was added to the Neospora antigen-coated microplates, which incubated at room temperature for 30 min. The reaction was revealed adding the supplied chromogen, and after $30 \mathrm{~min}$, the reaction was stopped. Plates were read at $630 \mathrm{~nm}$. Results are expressed as sample to positive $(\mathrm{S} / \mathrm{P})$ ratios, as recommended by the manufacturers. Serum samples with $\mathrm{S} / \mathrm{P}$ ratio is greater than or equal to 0.5 are classified as positive for $N$. caninum antibodies.

\section{Variables studied}

A questionnaire addressing epidemiological aspects of the farms relating to N. caninum including record of abortions and management system was used. The variables of breed, age, serological, lactation, and pregnancy status were recorded for each animal. The questionnaires were filled out in farms by field observations and recorded data in the cattle farms.

\section{Statistical analysis}

The estimated seropositivity was presented by the ratio between the number of positive blood tests and the total number of tests performed, with a confidence interval of 95\%. Data were described using descriptive statistics and analysis by chi-square test or ANOWA analysis. The statistical program SPSS package Ver 15 was used to perform the statistical analysis. Statistical significant level of difference was considered at $p<0.05$.

\section{Results}

N. caninum antibodies were detected in 196 sera (32.1\%) of 611 cows. Frequency of $N$. caninum in 25 cattle farms in Isfahan is shown in Table 1. The percentage of infection of animals in different farms ranged from $0.0 \%$ to $60 \%$ which is statistically significant difference $(P<0.05)$.

As it shown in Table 2, the frequency of N. caninum in different age groups is ranging from $29.3 \%$ to $33.0 \%$. There were no statistically significant differences among the age groups (Table 2). Of the 611 cows, 355 were pregnant, and 256 non-pregnant. N. caninum antibodies were detected in 140 (39.4\%) of pregnant and 66 (25.78\%) of non-pregnant cows. The differences between frequencies of $N$. caninum in pregnant and non-pregnant were statistically significant $(\mathrm{P}<0.05)$ (Table 2$)$. Of the 611 cows, 460 were lactated, and 151 were non-lactated. N. caninum antibodies were detected in 159 (34.6\%) of lactated and 37 (24.5\%) of non- lactated cows. 
The differences between frequencies of N. caninum in lactated and non-lactated cows were not statistically significant (Table 2). Of the 611 cows, 489 cows were industrial, and 122 were semi-industrial. N. caninum antibodies were detected in 151 (30.9\%) of industrial cows and $45(36.9 \%)$ of semi-industrial cows. There were no statistically significant differences between the frequencies of N. caninum in industrial and semi-industrial cows (Table 2). Of the 611 cows, 489 cows were feed with dried alfalfa+ silage +concentrate, and 122 were feed with fresh alfalfa+ dried alfalfa+ silage +concentrate (Table 2). N. caninum antibodies were detected in 151 (30.9\%) of cows that feed with dried alfalfa+ silage + concentrate, and 45 (36.9\%) of cows that feed with fresh alfalfa+ silage +concentrate. There were no statistically significant differences among the frequencies of $N$. caninum in two groups. Of the 611 cows, 493 cows had contact with watch dogs, and 118 had contact with watch dogs and wild caniide (Table 2). N. caninum antibodies were detected in 108 (21.9\%) and 88 (74.6\%) of cows that had contact with watch dogs and with both watch dogs and wild caniide. There were statistically significant differences between the frequencies of $N$. caninum in two groups.

\begin{tabular}{|c|c|c|c|c|}
\hline Farm No. & $\begin{array}{l}\text { Total No. of } \\
\text { cows in farm }\end{array}$ & $\begin{array}{c}\text { Number of } \\
\text { sampled cows }\end{array}$ & $\begin{array}{c}\text { Sero- } \\
\text { positive }\end{array}$ & $\begin{array}{c}\text { Prevalence }(\%) \\
\text { (95\% confidence interval) }\end{array}$ \\
\hline 1 & 300 & 39 & 11 & $28.2(16.5-43.7)$ \\
\hline 2 & 546 & 56 & 15 & $26.8(16.9-39.6)$ \\
\hline 3 & 1100 & 54 & 18 & $33.3(22.2-46.6)$ \\
\hline 4 & 200 & 48 & 13 & $27.1(16.5-40.9)$ \\
\hline 5 & 200 & 43 & 21 & $48.8(34.6-63.2)$ \\
\hline 6 & 260 & 32 & 10 & $31.2(17.9-48.6)$ \\
\hline 7 & 1800 & 36 & 8 & $22.2(11.7-38)$ \\
\hline 8 & 598 & 30 & 8 & $26.7(14.1-44.4)$ \\
\hline 9 & 300 & 28 & 10 & $35.7(20.7-54.2)$ \\
\hline 10 & 500 & 47 & 17 & $36.2(23.9-50.4)$ \\
\hline 11 & 300 & 47 & 11 & $23.4(13.6-37.2)$ \\
\hline 12 & 100 & 29 & 9 & $31(17.3-49.2)$ \\
\hline 13 & 50 & 8 & 3 & $37.5(13.6-69.4)$ \\
\hline 14 & 30 & 11 & 2 & $18.2(5.1-4.8)$ \\
\hline 15 & 30 & 8 & 2 & $25(7.1-59.1)$ \\
\hline 16 & 30 & 12 & 7 & $58.3(31.9-80.6)$ \\
\hline 17 & 31 & 8 & 4 & $50.0(21.5-78.4)$ \\
\hline 18 & 45 & 12 & 5 & $41.7(19.3-68)$ \\
\hline 19 & 100 & 7 & 3 & $42.9(15.8-74.9)$ \\
\hline 20 & 30 & 11 & 0 & $0.0(0-25.9)$ \\
\hline 21 & 25 & 12 & 4 & $33.3(13.8-60.9)$ \\
\hline 22 & 27 & 16 & 6 & $37.5(18.5-61.3)$ \\
\hline 23 & 15 & 7 & 4 & $57.1(25-84.1)$ \\
\hline 24 & 15 & 5 & 3 & $60(23.1-88.2)$ \\
\hline 25 & 15 & 5 & 2 & $40(11.8-76.9)$ \\
\hline Total & 7277 & 611 & 196 & $32.1(28.5-35.9)$ \\
\hline
\end{tabular}

Table 1: Frequency of N.caninum in 25 cattle herds in Isfahan with a history of abortion

\begin{tabular}{|c|c|c|c|c|}
\hline \multirow{2}{*}{ Category } & Level & $\begin{array}{c}\text { Number } \\
\text { tested }\end{array}$ & $\begin{array}{c}\text { Sero- } \\
\text { positive }\end{array}$ & $\begin{array}{c}\text { Prevalence (\%) } \\
\text { (95\% confidence interval) }\end{array}$ \\
\hline \multirow{2}{*}{ Cattle } & All & 611 & 196 & $32.1(28.5-35.9)$ \\
\hline \multirow{2}{*}{ Age(month) } & $\mathbf{1 2}$ & 109 & 32 & $29.3(21.6-38.4)$ \\
\cline { 2 - 5 } & $\mathbf{1 2 - 2 4}$ & 105 & 33 & $31.4(23.3-40.8)$ \\
\hline \multirow{2}{*}{\begin{tabular}{c} 
Pregnancy \\
\cline { 2 - 5 }
\end{tabular}} & $\mathbf{2 4}$ & 397 & 131 & $33.0(28.5-37.7)$ \\
\hline \multirow{2}{*}{$\begin{array}{c}\text { Lactation } \\
\text { state }\end{array}$} & Pregnant & 355 & 140 & $39.4(34.5-44.6)$ \\
\cline { 2 - 5 } & Lactated cows & 256 & 66 & $25.8(20.8-31.4)$ \\
\hline \multirow{2}{*}{ Farm type } & Non-lactate cows & 151 & 159 & $34.6(30.3-39)$ \\
\cline { 2 - 5 } & Industrial & 489 & 151 & $24.5(18.3-31.9)$ \\
\hline
\end{tabular}




\begin{tabular}{|c|c|c|c|c|}
\hline Category & Level & $\begin{array}{c}\text { Number } \\
\text { tested }\end{array}$ & $\begin{array}{c}\text { Sero- } \\
\text { positive }\end{array}$ & $\begin{array}{c}\text { Prevalence (\%) } \\
\text { (95\% confidence interval) }\end{array}$ \\
\hline \multirow{2}{*}{ Feed } & $\begin{array}{c}\text { Dried alfalfa+ silage } \\
\text { +concentrate }\end{array}$ & 489 & 151 & $30.9(26.9-35.1)$ \\
\cline { 2 - 5 } & $\begin{array}{c}\text { Fresh alfalfa+ dried alfalfa+ } \\
\text { silage +concentrate }\end{array}$ & 122 & 45 & $36.9(28.8-45.7)$ \\
\hline \multirow{2}{*}{$\begin{array}{c}\text { Contact with } \\
\text { caniide }\end{array}$} & Watch dog & 493 & 108 & $21.9(18.5-25.7)$ \\
\cline { 2 - 5 } & Watch dog and wild caniide & 118 & 88 & $74.6(66-81.5)$ \\
\hline
\end{tabular}

Table 2: Frequency of N.caninum in relation to age, pregnancy, lactation state,

farm type, feed condition and contact with caniide of dairy cow in Isfahan

\section{Discussion}

Studies of $N$. caninum antibody seroprevalence have been conducted in several parts of the world. In Iran, the presence of $N$. caninum antibodies has been described in cattle however, the role of dogs in the transmition is not well known but according to Malmasi, et al. (2007) study N. caninum antibodies were seen in 10 (20\%) of 50 household dogs and in 23 (46\%) of 50 farm dogs in Tehran $[12,13]$. A few serological surveys carried out for the detection of $N$. caninum infection have shown frequencies from 12.6 $\%$ to $32 \%$ in cattle, $37 \%$ in buffaloes and $3.22 \%$ in camel [14-17].

Because various diagnostic techniques and variety of cut-off points have been employed by different investigators comparison of different results is difficult. In the present study, N. caninum antibody sero-prevalence was 32.07\%, twice that obtained by Moore, et al. and Gondim, et al., who observed values of $16.6 \%$ and $15.6 \%$, respectively by indirect fluorescent antibody test (IFAT) [18,19].

After primary N. caninum infection the avidity of specific antibodies increases over time. Usually high avidity IgG responses are observed in cattle naturally infected for more than 6 months [3].

Among positive cattle, the frequencies of N. caninum in different age groups were ranging from $29.35 \%$ to $33.0 \%$ which it was not significant difference. According to study of Davison, et al. in Britain and Dyer, et al. in the United States the infection was less in those whose ages ranged 12-24 months when compared to those over 24 months [20,21]. This fact suggests the existence of sporulated N. caninum oocysts in the environment, which characterizes horizontal transmission, as observed by Dijkstra, et al. [9]. However, this feature of transmission has not proved frequent in some regions of the world, such as in California, where the major percentage of cattle is infected by the transplacental route, and most calves are born seropositive [22].

In this study we found that seroprevalence of N. caninum in pregnant cattle was significantly higher than non-pregnant cattle. Cattle with antibodies to N. caninum are more to abort than seronegative cows. Foetus may die in utero, resorbed, mummified, autolyzed or stillborn or born alive with or without clinical signs [3]. Detection of N. caninum antibody in this animal category is an alarm for losses during gestation and developing measures for the control of neosporosis in this animal category is very important.

$N$. caninum antibodies were detected in $21.90 \%$ and $74.57 \%$ of cows that had contact with only watch dogs and watch dogs+wild caniide, respectively. The differences between the frequencies of $N$. caninum in two groups were statistically significant means that wild caniide like foxes and jackals may play critical role in transmission of Neospora infection in dairy cattle farms of the region. Our results is on the contrary with Bartels, et al. study, who showed the presence of dogs on the farms as a significant associated factor, Barling, et al. observed that the presence of a dog among the cattle was a protective factor against N. caninum infection, explaining that the domestic dogs of the farm probably drove off stray and wild dogs that might be more important sources of infection than tame dogs $[23,24]$.

As to the general characteristics of the farms in relation to cattle, among variables analyzed, the feed sources silage and farmproduced concentrate behaved as protective factors against $N$. caninum infection. Cattle fed in this way would thus present a lower prevalence of infection by $N$. caninum. This finding, especially in relation to silage, may be related to preparation and storage, which hinder access by dogs; thus, avoiding contamination of the feed by N. caninum oocysts shed by the dogs. However, the study by Bartels, et al. showed that damp silage given during the summer is a risk factor [23]. Many mycotoxins suppress immune function by decreasing the proliferation of activated lymphocytes, impairing phagocytic function of macrophages, and suppressing cytokine production, but some induce hypersensitive responses in different dose regimes. The authors give as a probable cause the reactivation of latent $N$. caninum infection owing to the ingestion of mycotoxins in the silage, leading to intoxication with resulting immunosuppression.

\section{Conclusion}

These finding explain, at least in this region of Iran, there is a high percentage of $N$. caninum seropositive cattle and further investigation is needed for the confirmation of infection. In this study several important factors were investigated about the $N$. caninum seropositivity. We confirmed that present of watch dogs+wild caniide on farm related to increasing of seropositivity for $N$. caninum. The difference between $N$. caninum seropositivity on farms was due to differences in management conditions between 
farms. Further research is needed to confirm the effects of other pathogens such as bovine leukemia virus (BLV), bovine viral diarrhea virus (BVDV), Mycobacterium avium subspecies paratuberculosis (MAP) and mycotoxins on N. caninum infection in cattle.

\section{Acknowledgement}

The authors are thankful to "Isfahan Agriculture and Natural Resources Research and Education Center" and "Razi Vaccine and Serum Research Institute of Iran" for funding the research and technical support.

\section{References}

1. Dubey JP, Lindsay DS (1996) A review of Neospora caninum and neosporosis. Vet Parasitol 67: 1-59.

2. Hemphill A, Gottstein B (2000) A European perspective on Neospora caninum. Int J Parasitol 30: 877-924.

3. Dubey JP (2003) Review of Neospora caninum and neosporosis in animals. Korean J Parasitol 41: 1-16.

4. Gondim LF, McAllister MM, Pitt WC, Zemlicka DE (2004) Coyotes (Canis latrans) are definitive hosts of Neospora caninum. Int j parasitol 34: $159-61$.

5. Anderson ML, Reynolds JP, Rowe JD, Sverlow KW, Packham AE, et al. (1997) Evidence of vertical transmission of Neospora sp infection in dairy cattle. J Am Vet Med Assoc 210: 1169-72.

6. McAllister MM, Dubey JP, Lindsay DS, Jolley WR, Wills RA, et al. (1998) Dogs are definitive hosts of Neospora caninum. Int J Parasitol 28: $1473-8$.

7. Lindsay DS, Dubey JP, Duncan RB (1999) Confirmation that the dog is a definitive host for Neospora caninum. Vet Parasitol 82: 327-33.

8. McAllister MM, Bjorkman C, Anderson-Sprecher R, Rogers DG (2000) Evidence of point-source exposure to Neospora caninum and protective immunity in a herd of beef cows. J Am Vet Med Assoc 217: 881-7.

9. Dijkstra TH, Barkema HW, Bjorkman C, Wouda W (2002) A high rate of seroconversion for Neospora caninum in a dairy herd without an obvious increased incidence of abortions. Vet Parasitol 109: 203-11.

10. Thurmond MC, Hietala SK, Blanchard PC (1997) Herd-based diagnosis of Neospora caninum-induced endemic and epidemic abortion in cows and evidence for congenital and postnatal transmission. J Vet Diagn Invest 9: 44-9.

11. Lopez-Gatius F, Lopez-Bejar M, Murugavel K, Pabon M, Ferrer D, et al. (2004) Neospora-associated Abortion Episode over a 1-Year Period in a Dairy Herd in North-east Spain. J Vet Med B Infect Dis Vet Public Health 51: 348-52.

12. Sadrebazzaz A, Haddadzadeh H, Esmailnia K, Habibi G, Vojgani M, et al. (2004) Serological prevalence of Neospora caninum in healthy and aborted dairy cattle in Mashhad, Iran. Vet Parasitol 124: 201-4.

13. Malmasi A, Hosseininejad M, Haddadzadeh H, Badii A, Bahonar A (2007) Serologic study of anti-Neospora caninum antibodies in household dogs and dogs living in dairy and beef cattle farms in Tehran, Iran. Parasitol Res 100: 1143-5.

14. Nourollahi Fard SR, Khalili M, Aminzadeh A (2008) Prevalence of antibodies to Neospora caninum in cattle in Kerman province, South East Iran. Veterinarski Arhiv 78: 253-9.

15. Youssefi MR, Arabkhazaeli F, Hassan ATM (2009) Seroprevalence of Neospora caninum infection in rural and industrial cattle in northern Iran. Iranian J Parasitol 4: 15-8

16. Hajikolaei MRH, Goraninejad S, Hamidinejat H, Ghorbanpour M, Paryab R (2007) Occurrence of Neospora caninum antibodies in water buffaloes (Bubalus bubalis) from the south-western region of Iran. Bull Vet Inst Pulawy 51: 233-5.

17. Hosseininejad M, Pirali-Kheirabadi K, Hosseini F (2009) Seroprevalence of Neospora caninum infection in camels (Camelus dromedarius) in Isfahan province, center of Iran. Iranian J Parasitol 4: 61-4.

18. Moore DP, Campero CM, Odeon AC, Posso MA, Cano D, et al. (2002) Seroepidemiology of beef and dairy herds and fetal study of Neospora caninum in Argentina. Vet Parasitol 107: 303-16.

19. Gondim LF, Saeki H, Onaga H, Haritani M, Yamane I (1999) Maintenance of Neospora caninum tachyzoites using Mongolian gerbils (Meriones unguiculatus). N Z Vet 47: 36

20. Davison HC, Otter A, Trees AJ (1999) Estimation of vertical and horizontal transmission parameters of Neospora caninum infections in dairy cattle. Int J Parasitol 29: 1683-9.

21. Dyer RM, Jenkins MC, Kwok OCH, Douglas LW, Dubey JP (2000) Serologic survey of Neospora caninum infection in a closed dairy cattle herd in Maryland: risk of serologic reactivity by production groups. Vet Parasitol 90: 171-81.

22. Anderson ML, Palmer CW, Thurmond MC, Picanso JP, Blanchard PC, et al. (1995) Evaluation of abortions in cattle attributable to neosporosis in selected dairy herds in California. J Am Vet Med Assoc 207: 1206-10.

23. Bartels CJM, Wouda W, Schukken YH (1999) Risk factors for Neospora caninum-associated abortion storms in dairy herds in The Netherlands (1995 to 1997). Theriogenol 52: 247-57.

24. Barling KS, McNeill JW, Paschal JC, McCollum FT, Craig TM, et al. (2001) Ranch-management factors associated with antibody seropositivity for Neospora caninum in consignments of beef calves in Texas, USA. Prev Vet Med 52: 53-61. 


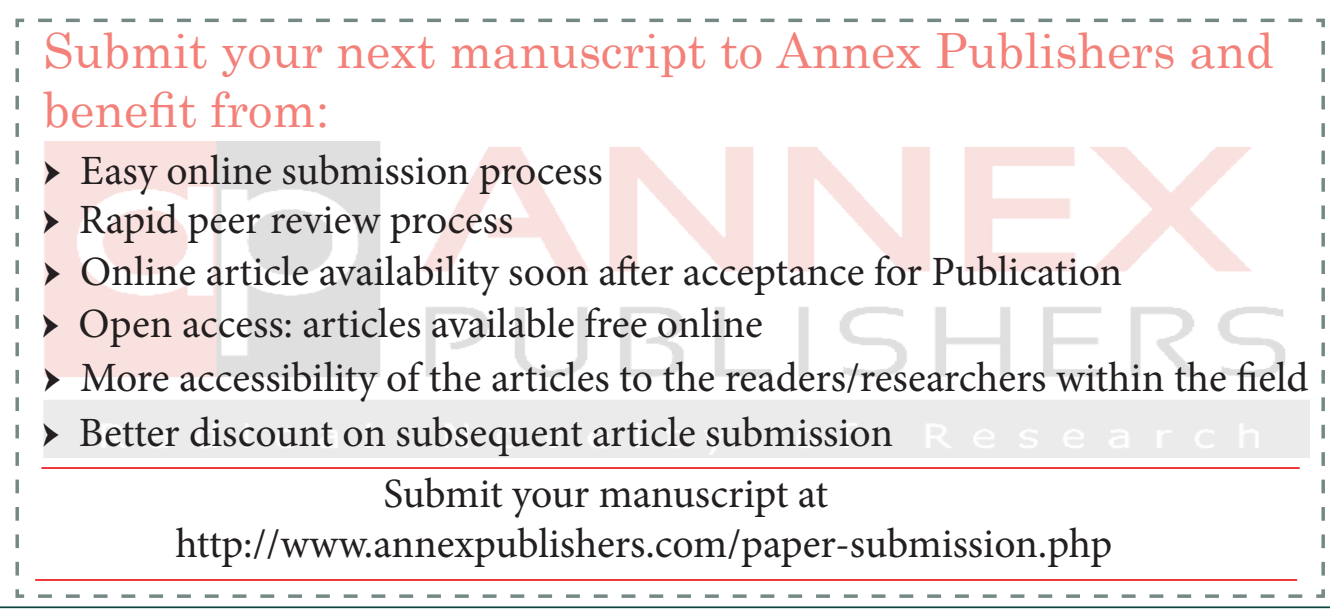

